\title{
The fourth largest market in the world
}

\section{Introduction}

The rich aroma of kretek clove cigarettes is one of the most evocative scents of Indonesia. But behind this redolent smoke haze few people contemplate the economic aspects of Indonesia's tobacco industry. Tobacco is the Indonesian government's largest source of revenue after oil, gas, and timber, ${ }^{1}$ recouping around US $\$ 4$ billion in excise in $1996,{ }^{2}$ about $10 \%$ of the Indonesian government's total tax revenue. ${ }^{3}$ Tobacco tax is an easy, reliable form of taxation, a steady, internal revenue, unlikely to suffer from any external shocks, and unlikely to create any sudden crisis, in contrast to the instability of oil revenue and other exportorientated products which are subject to the vagaries of international markets.

As the second largest employer after government, ${ }^{3}$ direct and indirect employment estimates for the Indonesian tobacco industry range from 4.3 million $^{2}$ to 17 million workers ${ }^{4}$ in farming, trading, transportation, and advertising, as well as those directly involved in manufacturing. ${ }^{5}$ The Indonesian government is critically dependent on the industry, as a means of sustaining employment levels, and for taxation revenue. As a result, opposition to the industry is discouraged and cigarette advertisers have free reign: "If NGO's [nongovernment organisations] get too verbal, they get warned that tobacco industries are vital to the nation's development."

\section{Young smokers}

Any visit to Indonesia will reveal the huge number of Indonesians, particularly men, who smoke. Male participation estimates range from $50 \%$ to $85 \%,{ }^{37}$ and "since $1970-72$, per adult consumption of cigarettes (all forms) has more than doubled, from 500 to 1180 per adult". ${ }^{3}$ In the short to mid-term these rates are only likely to increase because, as a report produced with the assistance of the Indonesian government enthusiastically noted in 1991: "Prospects for further market growth are considered good. Consumption levels per head of population are low by international standards. . . . A high proportion of Indonesia's population is in the younger age groups, meaning that the potential population of smokers will be growing rapidly in the next decade at least." 8

In 1985 a Jakarta study found that $49 \%$ of boys and $9 \%$ of girls aged 10-14 were daily smokers. $^{3}$ By contrast, a 1995 Indonesian health department survey (perhaps conservatively) estimated that $22.9 \%$ of urban 10 year olds, and $24.8 \%$ of rural 10 year olds smoke. ${ }^{9}$

It is uncertain to what degree the economic crisis has affected these participation rates but, in 1980, Indonesian households "spent more on tobacco than they did on clothing and footwear, on meat, or on medical and educational needs combined, and twice as much as they spent on festivals. The poorest households spent more on tobacco than they did on fish, meat, and eggs combined." ${ }^{7}$ In early 1998, industry investment analysts Morgan Stanley Asia Ltd estimated cigarette production and sales in Indonesia would not be significantly affected by the economic crisis. ${ }^{10}$ More recently, ING Barings Securities predicted that the largest cigarette company, Gudang Garam, would be one of the most likely Indonesian companies to survive the crisis. ${ }^{11}$

\section{Advertising and health information}

The dangers of smoking are not well promoted in Indonesia. Yet most kretek clove cigarettes have been found to contain around four times as much nicotine and tar as the strongest Marlboros. ${ }^{612}$ Kreteks are made up of a mixture of cloves and tobacco, usually about two-thirds tobacco and one-third cloves, plus an undisclosed mix of additives called "sauce". In addition to the enormous levels of tar and nicotine, research on the clove oil, eugenol, conducted by the American Health Foundation, has shown that it causes extensive lung damage when smoked. ${ }^{13}$ Yet the lack of health information about kreteks even extends to active misinformation. As recently as 1989, an article in the Business News magazine stated that kreteks could prevent heart disease and cancer. ${ }^{6}$ Packaging on another brand claimed the cigarette increases longevity and improves health. ${ }^{14}$ Health warnings such as "Smoking can harm your health" were introduced on cigarette packets in $1991,{ }^{3}$ but these remain small and unobtrusive.

In 1996, at the tailend of Soeharto's regime, Indonesia's health minister confirmed that "the government had no intention of trying to regulate smoking through legislation."15 The tobacco industry was the ninth biggest advertising spender by product category in $1996,{ }^{16}$ and as PT Sampoerna, one of the largest Indonesian tobacco companies, confidently noted in their 1995 annual report: "Being such an important economic component and the fact that the industry and the government have, all in all, a good working relationship with each other in the past, makes it doubtful that the government will radically change (for the worse) its current policies towards the industry as a whole."17

\section{Tobacco companies in Indonesia}

In contrast to the tobacco industry in other countries, Indonesia's industry is not dominated by multinationals. Multinational participants in the industry include Philip 


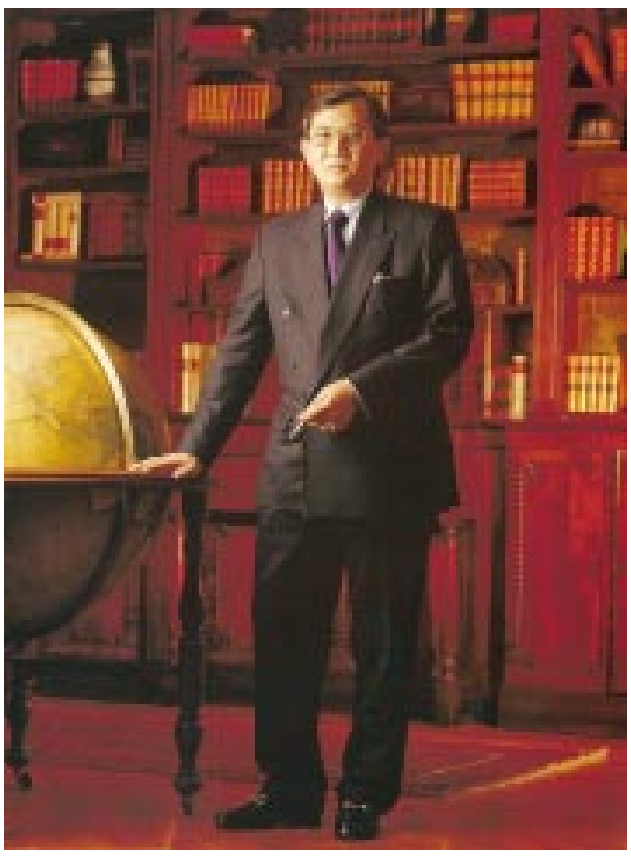

Putera Sampoerna, Indonesian tobacco billionaire, surrounded by his symbols of success.

Morris, PT BAT Indonesia (70\% owned by UK BAT Industries Ltd) ${ }^{18}$ and Rothmans (95\% owned by the Australian Rothmans Holdings Ltd), ${ }^{19}$ but as estimates from a number of sources reveal, in early 1998 these companies together only held about $15 \%$ of the Indonesian market. ${ }^{812} 2021$

Although there are between 155 and 363 tobacco companies in Indonesia, ${ }^{122} 23$ only four major ethnic-Chinese Indonesian companiesGudang Garam, Djarum, Sampoerna, and Bentoel-dominate the remaining market share. To give an idea of exactly how profitable the Indonesian market is for these companies, in 1997, of the seven known Indonesian billionaires (US\$), three were tobacco barons. ${ }^{2425}$

- Rachman Halim and the Wonowidjojo family (the publicly listed Gudang Garam brand) were worth US $\$ 4.9$ billion in November 1997, after the massive fall in the value of the rupiah.

- Budi Hartono and family (Djarum brand) were worth US $\$ 1$ billion with $20 \%$ market share of kreteks in early 1997.

- Putera Sampoerna (figure) and family (publicly listed-their brands include Dji Sam Soe, A-King, A-Mild, A-International) were worth US $\$ 1$ billion in November 1997, again after the drop in the rupiah.

For all these tobacco companies, Indonesia represents an attractive business environment, despite the current economic crisis. There are few of the restrictions tobacco companies are experiencing in Western markets, a practically unrestricted advertising and marketing regime, and the prospect of far less troublesome long-term profits. As Sampoerna's 1995 annual report states: "The culture of Indonesia is not litigious in nature and therefore the industry here does not expect the same exposure to litigation and potential lawsuits as do their American counterparts." ${ }^{17}$

Post-Soeharto, corruption and nepotism in Indonesia have become an openly acknowledged problem. Interestingly, however, only two of the Soeharto family members have directly participated in the lucrative tobacco industry. The first of these was Tommy Soeharto, who controlled the BCCP clove monopoly. To give an example of the sort of corporate regime that exists in Indonesia, at one stage BCCP paid clove farmers US $\$ 2$ per kilogram for their cloves, and then resold them to the tobacco companies for between $\$ 6.50$ and $\$ 7.50 .^{26}$ This monopoly was recently cancelled as part of the IMF "reforms". But the clove farmers are still unlikely to receive the amounts that the tobacco companies paid to Tommy Soeharto. These companies, being in a stronger position to bargain, will most likely be the beneficiaries of this new, "free" market.

The other Soeharto family member involved in the industry is Soeharto's cousin, Sudwikatmono. Sudwikatmono recently formed a partnership with Australian Rothmans Holdings Ltd, to "help the Company improve its knowledge of the Indonesian market." 19 In their 1997 annual report, Rothmans were enthusiastic about what then seemed to be a judicious alliance. In addition to his ties with Soeharto, Sudwikatmono also controlled the importation and distribution of overseas films. ${ }^{26}$

In the past the director of a Philip Morris affiliate has acknowledged that payoffs "are necessary for corporate survival and profitability," and "were essential to get favourable legislation enacted." ${ }^{27}$ Such an approach is a feature of Indonesian corporate and political culture. And while Philip Morris is an enormously powerful company in its own right, it also has powerful Asian connections. Philip Morris director Rupert Murdoch also owns Star TV Indonesia, ${ }^{28}$ which runs the subscription network Indovision. Indovision is owned by Bimantra Citra, a company belonging to Soeharto's second son Bambang. ${ }^{29}$ The political influence devolving from Murdoch's connections and ownership of such a powerful medium,,$^{30}$ ensures that Philip Morris is strategically positioned to increase its market share in Indonesia through its liaison with Bentoel's subsidiary PT Tresno, which produces Marlboro cigarettes ${ }^{22}$ : "The untapped markets of Asia, a region that easily accounts for a third of the world's cigarette consumption ... . [contain consumers] that barely know more than a handful of our many fine brands. ..."31

\section{Employment in the industry}

Little research has been carried out on employment conditions in the industry. Women in all areas of Indonesia's industrial sector are subject to appalling working conditions with extremely detrimental health effects, for minimal pay. ${ }^{32}$ In the traditional hand-rolled sector, women, who make up the bulk of the workforce, are expected to roll "at least 325 cigarettes an hour-one every ten seconds on average". ${ }^{12}$ It has also been 
recorded that child labour has been used in the industry. ${ }^{33}$ While Soeharto was still in government, there was only one legal union in Indonesia, SPSI. Its representation of workers was "heavily controlled by the government" and "poorly equipped to defend workers against employers". ${ }^{26}$ Unauthorised strikes were illegal and the military were used to control them. ${ }^{26}{ }^{34}$ Yet despite the ineffectiveness of SPSI, Sampoerna's 1995 annual report mentions a scheme for outsourcing their handrolled manufacturing to a number of different villages - even further increasing their workers' vulnerability, reducing access to union representation and decreasing their bargaining power.

\section{Health}

Indonesia's tobacco industry begs critical attention. For as the World Health Organisation (WHO) notes, reliable data regarding the number of Indonesians who die from cancer are "not available", ${ }^{3}$ yet WHO also estimates that 57000 Indonesians die each year as a result of tobacco use, ${ }^{3}$ and whereas tobacco-attributable mortality was around $3-4 \%$ in 1986 , "this number can be expected to increase dramatically within the next few decades". ${ }^{3}$ Certainly the Indonesian health department acknowledges there are 200000 new cases of cancer each year. ${ }^{9}$ Only $3.2 \%$ of these people ever receive hospital care, ${ }^{9}$ so obviously the degree to which these cancers are tobacco related requires further study. Unfortunately health resources are scarce, and given Indonesia's economic circumstances this lack of funding is only likely to get worse.

\section{Policy reform}

No matter what political reform might take place in Indonesia, it is unlikely to affect the tobacco industry. The government's first priority is to resuscitate the economy. The tobacco industry is strategically important and it is doubtful that the political and legislative actions being taken against the industry in Western countries will be implemented in Indonesia, at least in the short term. Despite Soeharto's political demise, Indonesia is still not a democracy and Indonesian anti-tobacco activists currently face an uphill struggle battling the tobacco industry. Opposition to the industry desperately requires increasing publicity and international pressure to institute advertising restrictions and increase the levels of health information available. At the very least this is an opportune moment to lobby for increased cigarette taxes, which could further support subsidies on other, more crucial consumer items. Certainly the industry can bear an increased tax burden and some loss of income, given their high profits and continuing resilience.

The recent tiered price increases on cigarettes (determined by each company's production levels ${ }^{35}$ ) in early 1998 signalled at least a step in the right direction, but it is not enough. This move by the government suggests fiscal expediency rather than any genuine desire to address Indonesia's huge mortality rate from tobacco. Certainly analysts predict that the larger tobacco companies will only benefit from this increase, with larger profit margins, rather than losing any market share. $^{3536}$

CATHERINE REYNOLDS

University of New South Wales, Australia; c.reynolds@unsw.edu.au

1 Anon. Indonesia-cigarette consumption drops, prices soaring. ANTARA-Asia Intelligence Wire, 23 March 1998.

2 Anon. Indonesia still haven for smokers. Fakarta Post 1998 May 31:1.

3 World Health Organisation. Tobacco or health: a global status report-Indonesia. Geneva: WHO, 1998. < http:// www.cdc.gov/nccdphp/osh/who/indonesi.htm>.

4 Shepherd C. Burning up in Asia: more smoking means a sharp rise in disease. Asiaweek 1996 Jul 5. <http:// www.pathfinder.com/@@ysgsTAcAZwG8rEmE/ Asiaweek/96/0705/feat9.html >.

5 Anon. Hike in cigarette prices may cause massive layoffs. fakarta Post 1998 Mar 25:2.

6 Schwarz A. Battle of the brands: kreteks' tar and nicotine levels create a clove scented controversy. Far Eastern Economic Review 199019 Apr:32-3.

7 Reid A. From betel-chewing to tobacco-smoking in Indonesia. F Asian Stud 1985;45:529-47.

8 Anon. The Sampoerna Group. Indonesia in the 1990s. London: Euromoney Publications, 1991.

9 Indonesian Health Department. Health for all: year 2000. $<$ http://www.depkes.go.id/english/hfa/index.htm>

10 Anon. Tougher times, but still puffing away. Summary and investment conclusion: Indonesia tobacco. Investext Broker Reports 1998 Feb 23.

11 Crampton T. In Asia, analysts sift fallout to pinpoint the companies likely to prosper. International Herald Tribune 1998 Oct 3-4:22.

12 Tanzer A. Smoking and no apologies. Forbes 1995 Aug 28:52-8.

13 McLellan D. Smoke thickens over clove cigarette inhalation study. Los Angeles Times 1986 Mar 21.

14 Frith K, ed. Advertising in Asia: communication, culture and consumption, Ames, Iowa: Iowa State University Press, 1996.

15 Anon. Where there's smoke there's money. Economic and business review Indonesia on-Line, 19 June 1996.

16 Anonymous. Advertising expenditure growing at a steady pace. Economic and business review Indonesia on-line, 22 Jan 1997 . <http:

17 PT HM Sampoerna. Annual report 1995. PT HM Sampoerna, 1995

18 Investor Responsibility Research Center. Tobacco industry report, 7th ed. Washington, DC: Investor Responsibility Research Center, 1998.

19 Rothmans. Annual report 1997. Rothmans (Australia), 1997. 0 Rothmans. Annual report 1996. Rothmans (Australia), 1996. Australian Stock Exchange Datadisc.

21 Hill H. 1996, The Indonesian economy since 1966: southeast Asia's emerging giant. Melbourne, Victoria: Cambridge University Press.

22 Anon. Cigarette industry still grows despite pressures and problems. ANTARA-Asia Intelligence Wire, 3 Dec 1997.

23 Anon. Indonesia: local cigarette production to fall. fakarta Post 1998 Jun 17:7.

24 Hiscock G. Asia's wealth club: who's really who in business-the top 100 billionaires in Asia. Sydney, New South Wales: Allen top 100 billionaires

25 Hiscock G. Market fallout: paper tigers burnt. The Weekend Australian 1997 Nov 1-2:21.

26 Schwarz A. A nation in waiting: Indonesia in the 1990s. Sydney, New South Wales: Allen and Unwin, 1994.

27 Clairmonte F. World tobacco: the dynamics of oligopolistic annexationism. I Contemporary Asia 1979;9:255-73.

28 Weber IG. The moral market: social vision and corporate strategy in Murdoch's rhetoric. Media Information Australia 1995;77:45-53.

29 Anon. Indonesia dims for Star. Daily Variety 1998 Oct 23:54

30 Atkins W. "Friendly and useful": Rupert Murdoch and the politics of television in SouthEast Asia, 1993-95. Media Information Australia 1995;77:54-64.

31 Philip Morris. Annual report 1996. Philip Morris, 1996. Australian Stock Exchange Datadisc.

32 Kemp M. The unknown industrial prisoner: women, modernisation and industrial health. Inside Indonesia modernisation

33 Anon. Child workers in the tobacco industry. Child workers in Asia 1987; Dec 4-5.

34 Pijar K. Military involvement seen hurting labor protection. fakarta Post 1997;Dec 11

35 Anon. Sentiments on cigarette shares strengthen. Bisnis Indonesia 1998; Mar 26.

36 Anon. Indonesia: PLN-PLN pinned under financial problem, power consumption down. Indonesian Commercial Newsletter 1998;Mar 30:50. 